\title{
Transfer and Expression of the Gene Encoding a Human Myeloid Membrane Antigen (gp150)
}

\author{
A. Thomas Look, Stephen C. Peiper, Matthew B. Rebentisch, Richard A. Ashmun, \\ Martine F. Roussel, Carl W. Rettenmier, and Charles J. Sherr \\ Departments of Hematology/Oncology, Pathology, and Tumor Cell Biology, \\ St. Jude Children's Research Hospital, Memphis, Tennessee 38101
}

\begin{abstract}
DNA from the human myeloid cell line HL-60 was cotransfected with the cloned thymidine kinase (tk) gene of herpes simplex virus into tk-deficient mouse $L$ cells. tk-positive recipients expressing antigens detected on $\mathrm{HL}-60$ cells were isolated with a fluorescence-activated cell sorter by use of a panel of monoclonal antibodies that detect epitopes on both normal and malignant myeloid cells. Independently sorted populations of transformed mouse cells showed concordant reactivities with four of the monoclonal antibodies in the panel (DU-HL60-4, MY7, MCS.2, and SJ-D1), which suggested that these antibodies reacted to products of a single human gene. A second round of DNA transfection and cell sorting was performed with donor DNA from primary transformants. Two different dominant selection systems were used to isolate secondary mouse $L$ cell and NIH/3T3 cell transformants that coexpressed the same epitopes. Analysis of cellular DNA from secondary mouse cell subclones with a probe specific for human repetitive DNA sequences revealed a minimal human DNA complement containing a characteristic set of restriction fragments common to independently derived subclones. Two glycoproteins, of 130,000 (gp130) and 150,000 (gp150) mol wt, were specifically immunoprecipitated from metabolically labeled lysates of mouse cell transformants and were shown to contain $\left[{ }^{35}\right.$ S]methioninelabeled tryptic peptides identical to those of analogous glycoproteins expressed in the donor human myeloid cell line. Kinetic and biochemical analyses established that gp130 is a precursor that differs in its carbohydrate moiety from $\mathrm{gp} 150$, the mature form of the glycoprotein detected on the cell surface. The isolation of human gene sequences encoding gp150 in a mouse cell genetic background provides the possibility of molecularly cloning the gene and represents a general strategy for isolating human genes encoding differentiation-specific cell surface antigens.
\end{abstract}

\section{Introduction}

Hematopoietic stem cells give rise to committed myeloid progenitors (granulocyte-monocyte colony forming units [CFUC]), ${ }^{1}$ which in turn differentiate into mature granulocytes and

\section{Received for publication 24 August 1984.}

1. Abbreviations used in this paper: CFU-C, granulocyte-monocyte colony forming units; endo $\mathrm{H}$, endo- $\beta$ - $N$-acetylglucosaminidase $H$; FCS, fetal calf serum; HAT, hypoxanthine/aminopterin/thymidine medium; tk, thymidine kinase.

J. Clin. Invest.

(c) The American Society for Clinical Investigation, Inc.

0021-9738/85/02/0569/11 \$1.00

Volume 75, February 1985, 569-579 monocytes $(1,2)$. Monoclonal antibodies that bind to epitopes of surface molecules expressed by subsets of cells within the human granulocytic and monocytic series also react with malignant cells from patients with myeloid leukemias, which suggests that the tumor cells represent clonal derivatives of myeloid progenitors blocked in various stages of differentiation (3). In a recent international workshop, a strong concordance of reactivity with both normal and malignant myeloid cells was demonstrated for three monoclonal antibodies: MY7, DUHL60-4, and MCS.2 (4). The antibodies DU-HL60-4 and MY7 precipitate glycoproteins with molecular weights of $\sim 150,000(5,6)$, which suggested that they could recognize epitopes on the same cell surface glycoprotein. Both DUHL60-4 and MY7 exhibit a panmyeloid pattern of reactivity, marked by binding to subsets of human CFU-C and normal granulocytic and monocytic cells at various stages of differentiation (3-7). All three antibodies bind to the human promyelocytic leukemia cell line HL-60 and to leukemic cells from $\sim 80 \%$ of patients with myeloid leukemia (3-7). In contrast, these antibodies do not bind to human lymphoid leukemia cells, normal B or T lymphocytes, platelets, erythrocytes, or erythroid progenitors defined by burst-forming units or colonyforming units (3-7). Despite extensive study of the pattern of reactivity of these antibodies with cells during myeloid differentiation, the function of the cell surface glycoprotein they identify is not known.

DNA-mediated transfer of genes encoding molecules expressed on the cell surface provides a powerful approach for isolating such genes and studying their regulation and expression. By cotransfection of mouse $L$ cells deficient in thymidine kinase (tk) with the herpes simplex virus tk gene, together with DNA from a human $T$ cell leukemia cell line, stable transformants that expressed human HLA class $I, \beta_{2}$-microglobulin, and $T$ cell differentiation antigens were obtained (8). The small proportions of transformants expressing these antigens were isolated with a fluorescence-activated cell sorter. The same strategy was recently used to isolate and clone the human transferrin receptor gene (9). We have applied a similar approach to isolate mouse fibroblasts expressing the human myeloid cell membrane glycoprotein gp150. Independently transformed mouse cell clones were found to contain a characteristic, limited subset of human DNA sequences and to express gp150 molecules precipitable with DU-HL60-4, MY7, and MCS. 2 monoclonal antibodies. Hence, the epitopes recognized by these antibodies are represented on the product of a single human gene.

\section{Methods}

Cell lines. $\mathrm{NIH} / 3 \mathrm{~T} 3(10)$ and $\mathrm{L}^{\left(\mathrm{tk}^{-}\right)}$cells (11) were grown as monolayer cultures in Dulbecco's modified Eagle's medium containing $10 \%$ fetal calf serum (FCS), penicillin $(100 \mu \mathrm{g} / \mathrm{ml})$, and streptomycin 
(100 $\mu \mathrm{g} / \mathrm{ml})$. The human promyelocytic cell line, HL-60 (12), was maintained in RPMI 1640 medium containing $12.5 \%$ FCS and antibiotics. Transformed L cells were grown in selective media (HAT) containing hypoxanthine $(100 \mu \mathrm{M})$, aminopterin $(0.4 \mu \mathrm{M})$, and thymidine $(16 \mu \mathrm{M})$. Transformed NIH/3T3 cells were cultured in medium containing 5\% FCS.

Preparation of cellular DNAs. Confluent flasks of cells growing as monolayers were washed in phosphate-buffered saline (PBS) and lysed in the flask with $40 \mathrm{ml}$ of $10 \mathrm{mM}$ Tris- $\mathrm{HCl}, \mathrm{pH} 7.4,10 \mathrm{mM}$ EDTA, $50 \mu \mathrm{g} / \mathrm{ml}$ RNAse, $100 \mu \mathrm{g} / \mathrm{ml}$ proteinase $\mathrm{K}$, and $1 \%$ sodium dodecyl sulfate (SDS). HL-60 cells growing in suspension were pelleted by centrifugation at $1500 \mathrm{rpm}$ for $5 \mathrm{~min}$, washed in PBS, and added to the same lysis buffer. After incubation for $4 \mathrm{~h}$ at $37^{\circ} \mathrm{C}$, nucleic acids were repeatedly extracted with an equal volume of Tris- $\mathrm{HCl}(\mathrm{pH} \mathrm{8.0})$ saturated phenol until a clear interphase was obtained. The aqueous phase was then extracted with an equal volume of phenol, chloroform, and isoamyl alcohol (25:24:1), and once with an equal volume of chloroform and isoamyl alcohol (24:1). $\mathrm{NaCl}$ was added to a final concentration of $0.2 \mathrm{M}$, and the DNA was precipitated with 2 vol cold $100 \%$ ethanol and spooled onto a glass rod. Dried precipitates were resuspended in $10 \mathrm{mM}$ Tris- $\mathrm{HCl}$ and $1 \mathrm{mM}$ EDTA, pH 7.4, at 200$500 \mu \mathrm{g} / \mathrm{ml}$ and dialyzed against the same solution.

Transfection of high molecular weight DNA. L (tk-) cells were cotransfected with the herpes simplex tk gene and human cellular DNA according to the calcium phosphate precipitation technique (13), as modified by Lowy et al. (14). In brief, $35-\mathrm{mm}$ petri dishes were seeded with $3 \times 10^{5}$ cells $1 \mathrm{~d}$ before transfection, and fresh medium was added $4 \mathrm{~h}$ before transfection. Cellular DNA (5 $\mu \mathrm{g})$ was sheared through a 25 -gauge needle, mixed with $1 \mu \mathrm{g}$ of tk plasmid DNA, and suspended in $190 \mu \mathrm{l}$ of solution containing $137 \mathrm{mM} \mathrm{NaCl}, 5 \mathrm{mM}$ $\mathrm{KCl}, 0.7 \mathrm{mM} \mathrm{Na} 2 \mathrm{HPO}_{4}, 6 \mathrm{mM}$ dextrose, and $20 \mathrm{mM}$ Hepes at $\mathrm{pH}$ 6.95. The DNA was then precipitated for $30 \mathrm{~min}$ at room temperature by the addition of $2 \mathrm{M} \mathrm{CaCl}_{2}$ in $0.01 \mathrm{M}$ Hepes buffer, $\mathrm{pH} 5.5$, to a final concentration of $10 \mathrm{mM}$, and then added to the culture. After 18 $h$ of incubation with the DNA precipitate, the cells were trypsinized and seeded into $75-\mathrm{cm}^{2}$ T-flasks. HAT medium was added after $24 \mathrm{~h}$ and changed every 3 or $4 \mathrm{~d}$. tk ${ }^{+}$colonies were enumerated after $12 \mathrm{~d}$, and the cells from 7-20 flasks were trypsinized and pooled for selection by fluorescence-activated cell sorting. $\mathrm{L}\left(\mathrm{tk}^{-}\right)$cells were transfected with human DNA alone, without the exogenous herpes simplex tk gene, as a control for the transfer of the tk gene from donor DNA (15,

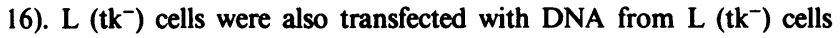
alone in order to enumerate HAT-resistant $\mathrm{tk}^{+}$revertants.

DNA from the cloned McDonough strain of feline sarcoma virus containing the v-fms oncogene (17) was cotransfected with $5 \mu \mathrm{g}$ of sheared cellular DNA onto NIH/3T3 cells by use of the technique described above. After $18 \mathrm{~h}$ of incubation with DNA precipitates, the cells were trypsinized and plated into $75-\mathrm{cm}^{2} \mathrm{~T}$-flasks with medium containing 5\% FCS. Foci of transformed cells were enumerated $12 \mathrm{~d}$ later and then allowed to overgrow the monolayer of untransformed NIH/3T3 recipients. Cells from 7-20 flasks were trypsinized, pooled, and repassaged once before selection by fluorescence-activated cell sorting. NIH/3T3 cells were transfected with donor DNA alone as a control for transfer of the N-ras transforming gene from HL-60 DNA $(18,19)$.

Monoclonal antibodies. A panel of monoclonal antibodies that react with antigens expressed on human myeloid cells, including the HL-60 cell line, is shown in Table I. Transformants were sorted by flow cytometry after staining with the antibodies DU-HL60-4, MY7, and SJ-D1. The latter antibody recognizes an epitope on cells that show positive fluorescence with DU-HL60-4, MY7, and MCS.2 (J. Mirro, St. Jude Children's Research Hospital, Memphis, TN, personal communication). Cells selected by flow sorting were tested for binding with the other myeloid-specific antibodies in the panel. Monoclonal antibodies were gifts of principal investigators in whose laboratories they were developed, with the exception of MY7 and MY9 (Coulter Immunology, Hialeah, FL) and Leu-M1 (Becton-Dickinson Monoclonal
Table I. Panel of Myeloid-specific Monoclonal Antibodies

\begin{tabular}{lll}
\hline Monoclonal antibody & Immunoglobulin isotype & References \\
\hline DU-HL60-1 & IgM & \\
DU-HL60-3 & IgM & \\
DU-HL60-4 & IgG2 & 5,7 \\
MY7 & IgG1 & \\
MY9 & IgG2b & 3,6 \\
SJ-D1 & & \\
MCS.2 & IgG1 & 20 \\
G2 & IgG1 & 4 \\
TG1 & IgM & 4 \\
G1120 & IgM & 4 \\
My-1 & IgM & 4 \\
IG10 & IgM & 21,22 \\
L4F3 & IgM & $23-25$ \\
Leu-M1 & IgM & 25,26 \\
& IgM & 27 \\
\hline
\end{tabular}

Center, Mountain View, CA). The monoclonal antibody W6/32 (Accurate Chemical \& Scientific Corp., Westbury, NY), specific for human HLA class I molecules, was used as a positive control to select for cells expressing a human gene product (8). Transfected cells were also tested for binding with the monoclonal antibody 12 (Coulter Immunology), specific for human HLA class II molecules (28). Mouse myeloma protein UPC10 (Litton Bionetics, Kensington, MD), isotype IgG2a, was used as a control for nonspecific binding.

Immunofluorescence and flow cytometry. Subconfluent cell cultures were released from the plastic substrate by incubation for $20 \mathrm{~min}$ in $\mathrm{Ca}^{++}$- and $\mathrm{Mg}^{++}$-free PBS containing $0.6 \mathrm{mM}$ EDTA, followed by a 5-min treatment with $10 \mu \mathrm{g} / \mathrm{ml}$ buffered trypsin (Gibco Laboratories, Grand Island, NY). HL-60 cells, growing in suspension culture, were pelleted by centrifugation and incubated for $30 \mathrm{~min}$ in a 1:4 dilution of human serum (AB blood group) at $10^{7}$ cells $/ \mathrm{ml}$. The cells were collected by centrifugation and resuspended in staining medium (Dulbecco's modified Eagle's medium containing 5\% FCS, $10 \mathrm{mM}$ Hepes, and $2 \mathrm{mM} \mathrm{Na}$ azide); $50-\mu \mathrm{l}$ aliquots, each containing $1 \times 10^{6}$ cells, were incubated for $30 \mathrm{~min}$ at $4^{\circ} \mathrm{C}$ with a titered excess of monoclonal antibody or mouse myeloma protein. The cells were washed three times and resuspended at the same concentration in staining medium containing a titered excess of affinity-purified, fluorescein isothiocyanateconjugated goat antibody to mouse immunoglobulins $\mathbf{G}$ and $\mathbf{M}$ (Tago Inc., Burlingame, CA). After incubation for $30 \mathrm{~min}$ at $4^{\circ} \mathrm{C}$, the stained cells were washed three times and resuspended in $0.5 \mathrm{ml}$ of staining medium containing $0.25 \mathrm{mM}$ propidium iodide. Cells were analyzed at a rate of 500 cells/s on an EPICS-V flow cytometer (Coulter Electronics Inc., Hialeah, FL) with a laser output of $800 \mathrm{~mW}$ at 488 $\mathrm{nm}$. Dead cells labeled with propidium iodide were excluded from the analysis (8). Fluorescein fluorescence was detected with a $510 \mathrm{~nm}$ interference filter and then a $525 / 40 \mathrm{~nm}$ band-pass filter. Frequency distribution profiles of the $\log _{10}$ fluorescence of 20,000 cells per sample were plotted, and a modal value of 1.0 was assigned to the cells stained with control myeloma protein. The brightest $2 \%$ of transfected NIH/ $3 \mathrm{~T} 3$ or $\mathrm{L}$ cells were sorted at 5,000 cells/dish into $35-\mathrm{mm}$ petri plates containing $2 \mathrm{ml}$ of medium. The cells were grown up and resorted until a separate population of positive cells was evident. The sorting gate was then set to sort the brightest $50 \%$ of the positive cells, and successive rounds of sorting were repeated until the population was $>80 \%$ positive for monoclonal antibody binding.

Detection of human repetitive DNA sequences in transfected mouse cell DNA. Cellular DNAs were digested with various restriction endo- 
nucleases (Bethesda Research Laboratories, Gaithersburg, MD), subjected to electrophoresis in $0.8 \%$ agarose gels, and transferred to nitrocellulose (29). Human DNA containing highly repetitive sequences was prepared by self-annealing of boiled, sonicated placental DNA to a $C_{0} t$ of 2 (where $C_{0}$ is the concentration of DNA in moles of nucleotide per liter and $t$ is the time in seconds [30]). Hybridization was performed at $65^{\circ} \mathrm{C}$ at a monovalent cation concentration of 0.6 $M$, and the double-stranded DNA was recovered by fractionation on hydroxylapatite (30). The repetitive human DNA was labeled to a specific activity of $1 \times 10^{8} \mathrm{dpm} / \mu \mathrm{g}$ by nick translation by use of $[\alpha-$ $\left.{ }^{32} \mathrm{P}\right]$ deoxycytidine 5 -triphosphate and $\left[\alpha^{32} \mathrm{P}\right]$ deoxythymidine $5^{\prime}$-triphosphate (31), and used in blot hybridization under stringent annealing conditions as described (32).

Metabolic labeling and immunoprecipitation. Subconfluent cultures were incubated for $3 \mathrm{~h}$ in either methionine-free RPMI 1640 medium containing $0.5 \mathrm{mCi}$ of $\mathrm{L}-\left[{ }^{35} \mathrm{~S}\right]$ methionine $(1,200 \mathrm{Ci} / \mathrm{mmol})$ per $\mathrm{ml}$ or in complete RPMI 1640 containing $1.0 \mathrm{mCi}$ of $\mathrm{D}-\left[2-{ }^{3} \mathrm{H}\right]$ mannose $(15$ $\mathrm{Ci} / \mathrm{mmol}$ ) per $\mathrm{ml}$. In some experiments, cells were pre-incubated for 6 h with $2.0 \mu \mathrm{g} / \mathrm{ml}$ tunicamycin before labeling was done in order to inhibit cotranslational addition of $\mathrm{N}$-linked oligosaccharide chains (33). For kinetic studies, suspension cultures of HL-60 cells $\left(2 \times 10^{6}\right.$ cells/ $\mathrm{ml}$ ) were incubated for $30 \mathrm{~min}$ in methionine-free medium, labeled for $15 \mathrm{~min}$ with $\left[{ }^{35} \mathrm{~S}\right]$ methionine, centrifuged, and resuspended in RPMI 1640 medium containing an excess of unlabeled methionine. At various times of chase, aliquots were removed and the cells were recovered by centrifugation. The cells were lysed in $100 \mathrm{mM}$ Hepes buffer, pH 7.4, containing $150 \mathrm{mM} \mathrm{NaCl}, 20 \mathrm{mM}$ EDTA, $1 \%$ Triton $\mathrm{X}-100$, and $0.1 \%$ SDS with $2 \%$ aprotinin (Sigma Chemical Co., St. Louis, $\mathrm{MO}$ ), and $1 \mathrm{mM}$ phenylmethylsulfonyl fluoride as protease inhibitors. Immunoprecipitation was carried out as previously described (17) with protein A-Sepharose CL-4B (Pharmacia Fine Chemicals, Piscataway, NJ) as the immunoadsorbent. The SDS-polyacrylamide gel electrophoresis system of Laemmli (34) was used. Apparent molecular weights of proteins were estimated from their mobilities relative to known polypeptide standards.

Radioiodination of cell surface proteins. HL-60 cells $\left(5 \times 10^{7}\right)$ or $\mathrm{NIH} / 3 \mathrm{~T} 3$ transformants (one $75-\mathrm{cm}^{2}$ flask at confluence) were washed twice with PBS and then incubated in $1.0 \mathrm{ml}$ PBS containing $1.0 \mathrm{mCi}$ $\mathrm{Na}^{125}$ ( Amersham Corp., Arlington Heights, IL), $75 \mu \mathrm{g}$ lactoperoxidase and $8.8 \mu \mathrm{g}$ glucose oxidase (Sigma Chemical Co.), and $5 \mathrm{mM} \mathrm{D}-$ glucose for $15 \mathrm{~min}$ at room temperature with occasional gentle mixing.
The cells were washed twice with PBS before lysis. Immunoprecipitation and electrophoretic analysis were carried out as described above.

Enzymatic digestions of immunoprecipitates. Metabolically labeled glycoproteins were immunoprecipitated, and the precipitates were washed five times in lysis buffer and three more times in lysis buffer lacking SDS and EDTA. The precipitates were divided and incubated for $20 \mathrm{~h}$ at $37^{\circ} \mathrm{C}$ in $20 \mu \mathrm{l}$ of either (a) $0.3 \mathrm{U}$ of Streptomyces griseus endo- $\beta$ - $N$-acetylglucosaminidase $\mathrm{H}$ (endo $\mathrm{H}$ ) (EC 3.2.1.96) (Sigma Chemical Co.) per $\mathrm{ml}$ in $150 \mathrm{mM}$ sodium citrate (pH 5.3); or (b) 1.0 $\mathrm{U}$ of Vibrio cholerae neuraminidase (EC 3.2.1.18) (Calbiochem-Behring Corp., American Hoechst Corp., San Diego, CA) per $\mathrm{ml}$ in $50 \mathrm{mM}$ sodium acetate (pH 5.5) containing $150 \mathrm{mM} \mathrm{NaCl}$ and $4 \mathrm{mM} \mathrm{CaCl}$. Parallel control incubations were performed by use of the indicated buffer solutions without enzymes. Reactions were terminated by the addition of $40 \mu \mathrm{l}$ gel sample buffer and heating to $100^{\circ} \mathrm{C}$ for $2 \mathrm{~min}$ before loading onto gels.

Peptide mapping. Metabolically labeled polypeptides in polyacrylamide gel slices were oxidized with performic acid and digested in L(tosylamido-2-phenyl) ethyl chloromethyl ketone-treated trypsin as described (35). Eluted peptides were separated in two dimensions on cellulose-coated, thin layer plates $(20 \times 20 \mathrm{~cm}$; E. Merck, Darmstadt, Germany) by electrophoresis at $1,000 \mathrm{~V}$ for $20 \mathrm{~min}$ in acetic acidformic acid-water (15:5:80, pH 1.9), followed by ascending chromatography in 1-butanol-pyridine-acetic acid-water (65:50:10:40) containing $7 \%(\mathrm{wt} / \mathrm{vol})$ diphenyloxazole. Dried plates were exposed to Kodak XAR-5 film (Eastman Kodak Co., Rochester, NY) for fluorography.

\section{Results}

Strategy for DNA-mediated gene transfer. The uptake of high molecular weight DNA precipitates by transfected mouse cell lines, such as L cells or NIH/3T3 cells, leads to stable incorporation of the donor DNA in $<0.1 \%$ of the recipient cells $(14,15)$. Despite the low efficiency of transformation, cotransfection of two unlinked genes leads in general to incorporation of both genetic markers in at least one half of the successfully transformed population. Hence, dominant selectable markers can be used to obtain cells that have acquired exogenous DNA, among which at least $50 \%$ should express other donor

Table II. Cotransfection of Human DNA and Selectable Markers into Mouse Fibroblasts

\begin{tabular}{|c|c|c|c|c|c|}
\hline \multirow[b]{2}{*}{ Experiment No. } & \multirow[b]{2}{*}{ Donor DNA } & \multirow[b]{2}{*}{ Selection system } & \multicolumn{3}{|c|}{ Number of transformants } \\
\hline & & & Total No. & No. plates & Average/plate* \\
\hline \multicolumn{6}{|c|}{ Primary transfections } \\
\hline 1 & HL-60 & tk, L & 22,900 & 7 & $3,271(4)$ \\
\hline 2 & HL-60 & $\mathrm{tk}, \mathrm{L}$ & 50,800 & 6 & $8,467(16)$ \\
\hline 3 & HL-60 & tk, L & 83,200 & 22 & $3,782(9)$ \\
\hline 4 & HL-60 & $\mathrm{v}-\mathrm{fms}, \mathrm{NIH} / 3 \mathrm{~T} 3$ & 9,350 & 10 & $935(3)$ \\
\hline 5 & HL-60 & v-fms, NIH/3T3 & 3,690 & 6 & $615(4)$ \\
\hline \multicolumn{6}{|c|}{ Secondary transfections $\ddagger$} \\
\hline 6 & 1 (DU-HL60-4) & tk, L & 39,200 & 8 & 4,900 \\
\hline 7 & 1 (DU-HL60-4) & v-fms, NIH/3T3 & 15,800 & 8 & $1,975(3)$ \\
\hline 8 & 1 (SJ-D1) & tk, $\mathrm{L}$ & 35,700 & 8 & 4,462 \\
\hline 9 & 1 (MY7) & tk, L & 35,800 & 8 & 4,475 \\
\hline
\end{tabular}

* Numbers in parentheses are the numbers of $\mathrm{L}$ cell colonies or NIH/3T3 cell foci obtained in the absence of the selectable marker. $\ddagger$ Donor DNAs for secondary transfections were from primary transformants isolated in experiment 1 . The primary transformants were selected with the monoclonal antibodies indicated. 
genes $(15,16,18)$. Cells transformed by genes that encode cell surface glycoproteins can express donor antigens detectable by immunofluorescent procedures. Fluorescence-activated cell sorting has been used to enrich for populations of recipient cells that have stably incorporated such genes $(8,9)$. In general, the primary transformants contain about 1,500-2,000 kilobase pairs of donor DNA, or $\sim 0.1 \%$ of one human genome equivalent. A second round of DNA transfection and cell sorting would therefore be expected to yield recipient cells containing a very limited subset of human DNA sequences, among which would be the gene of interest. Such sequences can be detected in restriction digests by use of human DNA probes consisting of highly reiterated sequence families that are represented throughout the human genome $(17,19)$.
Isolation of mouse cell transformants that express human cell surface antigens. Two separate cotransfection systems were used to test whether mouse cells that express human myeloid differentiation antigens could be isolated after DNA-mediated gene transfer. In the first, DNA from the human myeloid cell line HL-60 was cotransfected with the molecularly cloned herpes simplex virus tk gene into tk-deficient mouse $L$ cells (36). In three separate transfection experiments, $2-8 \times 10^{4} \mathrm{~L}$ $\left(\mathrm{tk}^{+}\right)$cell colonies resistant to HAT medium were obtained (Table II). Transfection performed with HL-60 DNA alone yielded an average of only 10 colonies per plate. The low tk background could be due to acquisition of the HL-60 tk gene by the recipient cells or, possibly, to reversion of $L\left(t^{-}\right)$cells. HAT-resistant colonies were not observed in control transfection
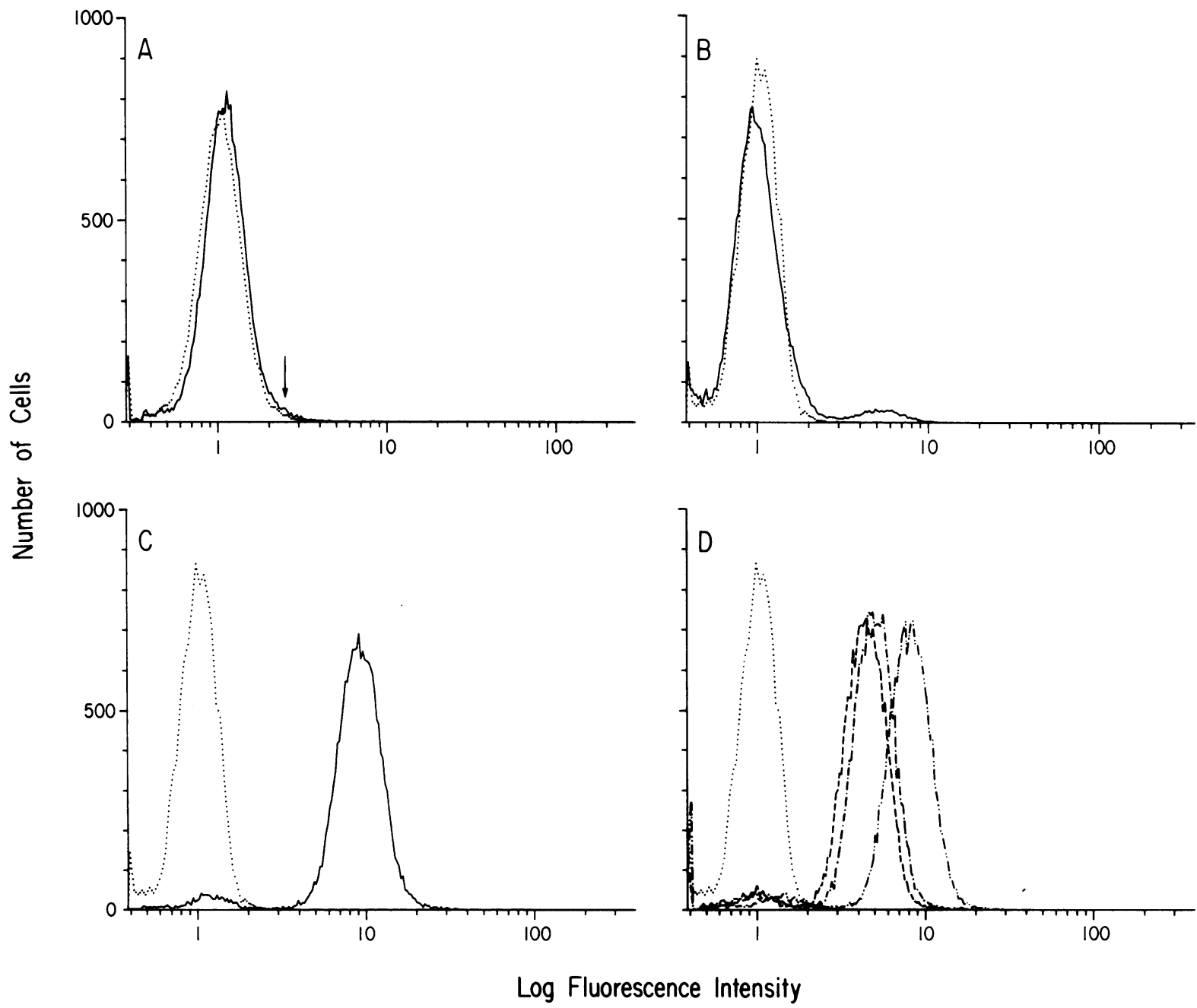

Figure 1. Selection by fluorescence-activated cell sorting of mouse $\mathrm{L}$ cell transformants expressing the human myeloid differentiation antigen recognized by the monoclonal antibody DU-HL60-4. In $A-C$, the fluorescence recorded by use of DU-HL60-4 (-) was compared with the control fluorescence profile obtained with an IgG2a mouse myeloma protein $(\cdots)$. When pooled $\mathrm{L}$ cells were analyzed after transfection with HL-60 DNA $(A)$, the profile obtained after staining with DU-HL60-4 was identical to the control profile. The $2 \%$ of cells with the brightest fluorescence were sorted, grown up, and resorted (denoted by the arrow in $A$ ). After two rounds of sorting a
DU-HL60-4 fluorescence-positive subpopulation was evident, comprising $3.7 \%$ of the cells $(B)$. After two more rounds of sorting to select for the DU-HL60-4 positive cells, $96.8 \%$ of the cells showed positive fluorescence $(C)$. When these cells were tested against a panel of monoclonal antibodies specific for human myeloid differentiation antigens expressed by HL-60 cells $(D)$, positive fluorescence profiles were obtained with MCS.2 (---), MY7 (.- - ), and SJ-D1 $(\cdot-\cdots)$. The other monoclonal antibodies in the panel (Table I) showed a negative fluorescence profile, identical to that obtained with control mouse myeloma protein. 
experiments performed with DNA from $\mathrm{L}\left(\mathrm{tk}^{-}\right)$cells, in agreement with previous observations that spontaneous reversion to the tk ${ }^{+}$phenotype is infrequent (15).

NIH/3T3 cells were also cotransfected with HL-60 DNA and a plasmid containing the molecularly cloned v-fms transforming gene from the McDonough strain of feline sarcoma virus (17). In this system, morphologically transformed NIH/ 3T3 cells that acquire the v-fms gene overgrow contactinhibited fibroblasts that do not incorporate the marker. In two transfection experiments, 3-9 $\times 10^{3}$ foci of transformed cells were obtained with HL-60 DNA in combination with the $v-f m s$ gene, whereas only 3-6 transformed foci per plate were obtained without the marker (Table II). No foci were observed in control plates transfected with NIH/3T3 cell DNA. Again, the background foci in cultures transfected with DNA from HL-60 cells could represent spontaneous transformation of $\mathrm{NIH} / 3 \mathrm{~T} 3$ cells (37) or transformation mediated by an active oncogene (N-ras) previously identified in HL-60 DNA $(18,19)$.

Individual libraries of mouse cells cotransfected with HL60 DNA were grown and selected by fluorescence-activated cell sorting for the presence of cells reacting with the monoclonal antibodies DU-HL60-4, MY7, and SJ-D1 (Fig. 1). After 2\% of cells with the brightest fluorescence were sorted, grown up, and resorted through from three to five successive rounds, cell populations were obtained that were $>80 \%$ reactive with each monoclonal antibody by immunofluorescence analysis. Eleven individual positive cell populations were obtained with each of three monoclonal antibodies from libraries generated with both the tk and v-fms selection systems. When tested for reactivity with a panel of human myeloid differentiationspecific monoclonal antibodies (Table I), each of the independently sorted cell populations was positive by immunofluorescence with DU-HL60-4, MY7, SJ-D1, and MCS.2 antibodies, regardless of which antibody was used for the selection (Fig. 1). By contrast, negative fluorescence profiles identical to those obtained with control myeloma proteins were obtained with other monoclonal antibodies specific for human myeloid antigens (Table I) or human histocompatibility class I (W6/32) and class II (I2) framework determinants. As additional controls, two of the transfected $\mathrm{L}$ cell libraries were sorted with the monoclonal antibody W6/32 specific for human class I histocompatibility antigens (8). After three successive rounds of sorting, positive cell populations expressing HLA gene products were obtained. These cells did not react with any of the panel of monoclonal antibodies specific for human myeloid antigens (Table I).

To enrich for DNA sequences encoding human myeloid differentiation antigens, a series of secondary transformants was selected. DNA was extracted from three different $\mathrm{L}$ cell populations that had been independently selected for reactivity with the monoclonal antibodies DU-HL60-4, MY7, and SJD1. These DNAs were cotransfected with selectable markers into $\mathrm{L}\left(\mathrm{tk}^{-}\right)$cells or $\mathrm{NIH} / 3 \mathrm{~T} 3$ cells (Table II). After three successive rounds of sorting with the same monoclonal antibodies that were used to select the corresponding primary transformants, fluorescence-positive secondary transformants were obtained with DU-HL60-4 in both L cells and NIH/3T3 cells, and with SJ-D1 in $\mathrm{L}$ cells. Subclones of the three individual populations of antigen-positive secondary transformants were grown from single cells, either from agar colonies (v-fms-transformed $\mathrm{NIH} / 3 \mathrm{~T} 3$ cells) or by plating at limiting dilution ( $\mathrm{L}$ cells), and the subclones were analyzed for monoclonal antibody binding. Six antigen-positive NIH/3T3 and six $\mathrm{L}$ cell secondary subclones were examined, each of which also showed positive surface fluorescence with the monoclonal antibodies DU-HL60-4, MY7, SJ-D1, and MCS.2 but not with the other monoclonal antibodies in the panel (Fig. 2). Hence, the concordance of reactivities of transformed cells with four monoclonal antibodies was independent of the selective system used for DNA-mediated gene transfer, did not depend on which of the monoclonal antibodies was used in cell selection, and was observed after serial rounds of DNA-mediated gene transfer.

Cells expressing myeloid antigens contain human DNA. The cellular DNAs of primary transformants and cloned secondary transformants from independent transfection experiments were analyzed by Southern blotting for the presence of restriction fragments hybridizing to a radiolabeled probe prepared from human repetitive DNA sequences. We reasoned that the secondary transformants would contain only a limited subset of human DNA sequences, so that human DNA restriction fragments shared between the DNAs of independently derived clones would be those that encode the myeloid antigens. Most human DNA fragments, regardless of their coding sequences, would be expected to contain members of highly reiterated sequence families that would anneal to the probe, whereas mouse DNA would not anneal to the probe under stringent hybridization conditions. A similar approach was used to demonstrate human transforming gene sequences transfected into mouse NIH/3T3 cells (compare reference 18).

Fig. 3 shows a Southern blot analysis of DNA from several mouse cell transformants. After digestion with the restriction

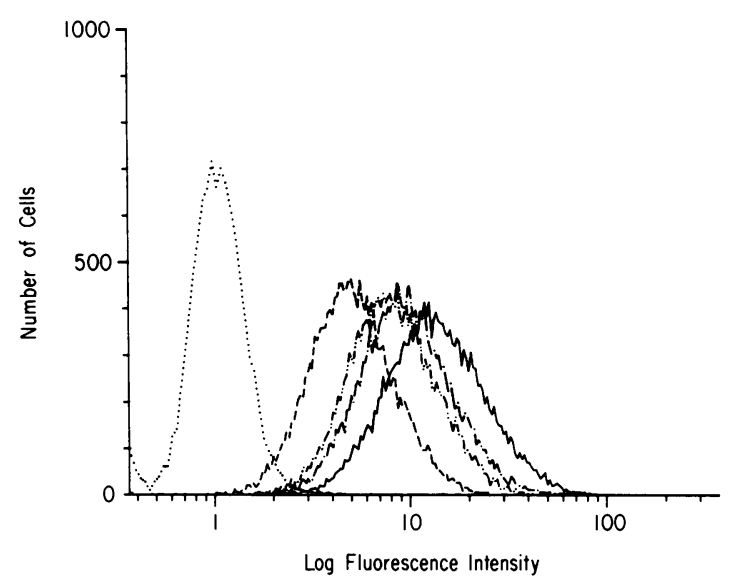

Figure 2. Flow cytometric analysis of cell surface binding of human myeloid differentiation-specific monoclonal antibodies to a cloned secondary NIH/3T3 transformant. The subclone was derived from $\mathrm{NIH} / 3 \mathrm{~T} 3$ cells cotransfected with cellular DNA from a primary L cell transformant together with the $v-f m s$ gene. The cells were sorted three successive times to enrich for monoclonal antibody DU-HL604 positive cells, and subcloned as colonies from single cells in agar. The positive fluorescence profiles obtained by testing of cells of a representative subclone with monoclonal antibodies DU-HL60-4 (-) MCS.2 (-- ), MY7 (.- . ), and SJ-D1 (..-..) are shown. The other antibodies in the panel (Table I) gave negative fluorescence profiles identical to that obtained with control mouse myeloma protein $(\cdots)$. 


\section{BamHI}

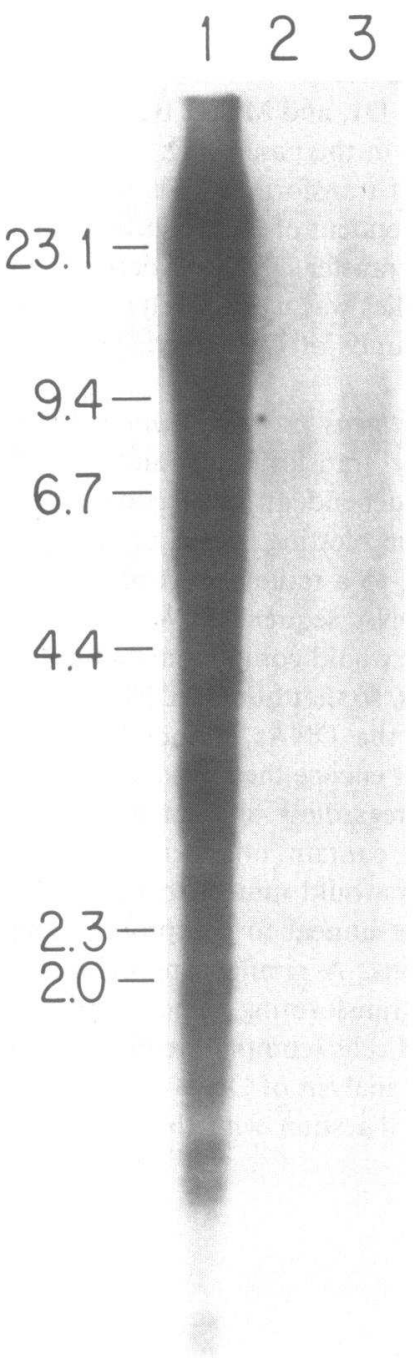

$\mathrm{BamHI}$

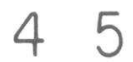

$+$

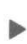

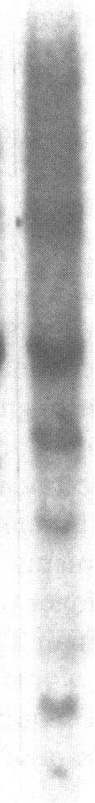

EcoRI<smiles>[C-]C1[CH-]C1</smiles>

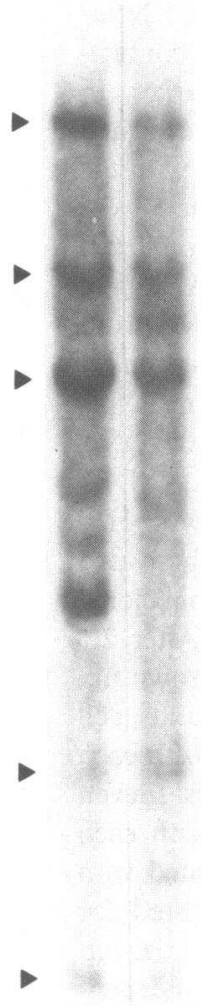

Hind III<smiles>[O-][O-]</smiles>

Figure 3. Southern blot analysis of human DNA sequences in mouse cell transformants. DNA samples were digested with the indicated enzymes before electrophoresis and transfer to nitrocellulose. Hybridization was performed by use of radiolabeled human DNA consisting of highly reiterated sequence families. The different lanes shown in the figure were composed from the same blot. DNA samples were analyzed from a primary $\mathrm{L}$ cell transformant (lane 1 ), control $\mathrm{L}$ cells (lane 2), control NIH/3T3 cells (lane 3), a secondary NIH/3T3 cell

endonuclease BamHI, DNA from primary $L$ cell transformants (Table II, experiment 1 ) reacted strongly with the radiolabeled human DNA probe and showed a diffuse hybridization pattern, reflecting the presence of many heterodisperse human DNA restriction fragments (lane 1 ). Under the same hybridization conditions, DNA from mouse $\mathrm{L}$ cells (lane 2) and NIH/3T3 cells (lane 3) did not anneal to the probe. The DNA from secondary transfected subclones also hybridized to the probe but, unlike the DNA of primary transformants, rendered discrete bands. Representative results are shown with the DNA of two secondary subclones obtained with NIH/3T3 cells (lanes transformant (lanes 4, 6, and 8 ) and a secondary $\mathrm{L}$ cell transformant (lanes 5,7 , and 9). The secondary subclones were derived from independent experiments performed with different selection systems. The major restriction fragments in common among the independent subclones are indicated by the triangles. The positions of bacteriophage lambda HindIII fragments of known length (noted in kilobase pairs) are indicated to the left of the figure.

4, 6, and 8) or L cells (lanes 5, 7, and 9). Both subclones were independently derived in separate experiments (Table II, experiments 6 and 7) in which the same donor DNA but different selection systems and recipient cell lines were used. After digestion with BamHI, at least four human DNA restriction fragments of similar length were detected in both subclones (lanes 4 and 5). Analogous results were obtained with EcoRI (lanes 6 and 7) and HindIII (lanes 8 and 9), although the band patterns and sizes of the common fragments differed with each enzyme. Taken together, the results suggest that the complexity of the gene sequences encoding the antigens rec- 
ognized by DU-HL60-4, MCS.2, MY7, and SJ-D1 is equal to or less than the combined complexity of the DNA fragments shared by the subclones, or $<50$ kilobase pairs. These data are most consistent with the hypothesis that the four epitopes are expressed on a product of a single gene.

Biochemical analysis of the mobilized gene product. The monoclonal antibodies DU-HL60-4 and MY7 were reported in separate studies $(5,6)$ to react with glycoproteins of apparent molecular weights of 150,000 . Fig. 4 shows that MY7 (lane 1) and DU-HL60-4 (lane 3) each specifically immunoprecipitated two $\left.{ }^{35} \mathrm{~S}\right]$ methionine-labeled polypeptides of 130,000 and 150,000 mol wt from lysates of metabolically labeled HL-60 cells. Both polypeptides were also precipitated by the monoclonal antibody MCS.2, although under the conditions used, precipitation was less efficient. The two polypeptides, here designated gp130 and gp150, respectively, were not precipitated with a control myeloma protein (lane 2) or by other monoclonal antibodies in the panel (Table I). Polypeptides similar to those precipitated from HL-60 cells were also recovered from metabolically labeled lysates of secondary mouse cell transformants (see Fig. 4, lane 5 for representative data with DU-HL60-4). By contrast, transformed mouse cells transfected with the cloned v-fms oncogene without HL-60 DNA did not yield products specifically precipitated by DU-HL60-4 (lane 7) but did express v-fms-coded glycoproteins (data not shown). Hence, the epitopes recognized by DU-HL60-4, MY7, MCS.2, and SJ-D1 are represented in both gp130 and gp150, and mouse cell transformants that coexpress these epitopes at their cell surface synthesize both classes of molecules.

The primary structures of gp130 and gp150 molecules expressed in donor HL-60 cells and in recipient NIH/3T3

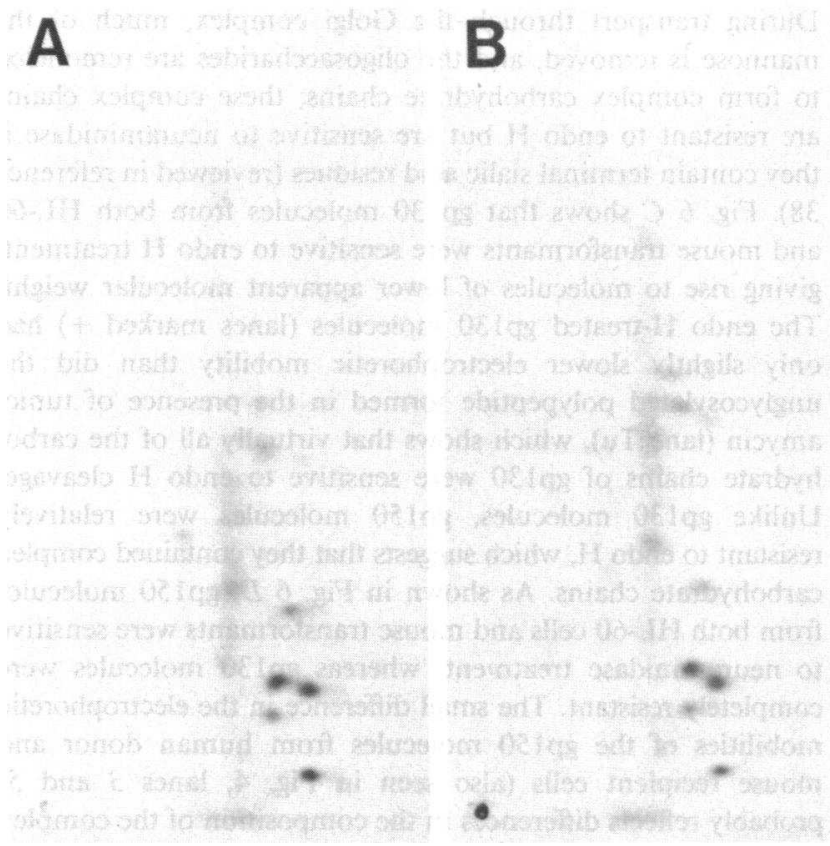

Figure 5. Two-dimensional tryptic mapping of $\left[{ }^{35}\right.$ S $]$ methionine-labeled polypeptides immunoprecipitated by the monoclonal antibody DU-HL60-4 from HL-60 cells and secondary NIH/3T3 transformants. The indicated polypeptides were oxidized with performic acid and digested with trypsin. Digests were applied at the origin in the lower lefthand corner of each panel and were separated first by electrophoresis at $\mathrm{pH} 1.9$ from left to right (anode at left) and then

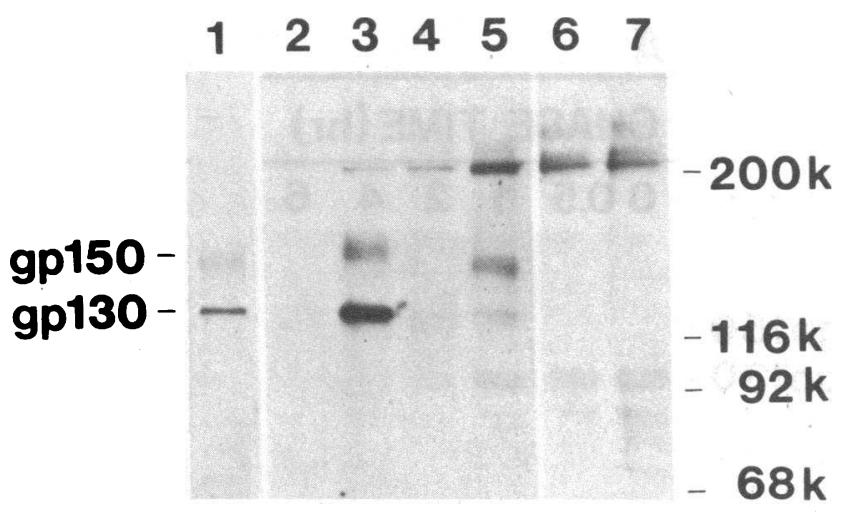

Figure 4. Immune precipitation of gp130 and gp150 from human HL-60 cells and secondary mouse transformants. Cells were metabolically labeled for $3 \mathrm{~h}$ with $\left.{ }^{35} \mathrm{~S}\right]$ methionine, detergent lysates were precipitated with antibody, and the radiolabeled products were analyzed in polyacrylamide gels containing SDS. Lysates prepared from HL-60 cells (lanes 1-3), from recipient mouse cells expressing surface epitopes detected by DU-HL60-4, MY7, MCS.2, and SJ-D1 (lanes 4 and 5) and from control mouse cells transformed by $\mathrm{v}-\mathrm{fms}$ alone (lanes 6 and 7) were reacted with MY7 (lane 1), DU-HL60-4 (lanes 3,5 , and 7), or a control myeloma protein (lanes 2, 4, and 6). The positions of gp 150 and gp130 are indicated at the left and those of protein standards of known molecular weight are shown at the right. $\mathbf{k}$, thousands.

secondary transformants were compared by two dimensional analysis of methionine-containing tryptic peptides. Fig. 5 shows that $\left[{ }^{35}\right.$ S]methionine-labeled $\mathrm{gp} 150(A)$ and $\mathrm{gp1} 30(B)$ from

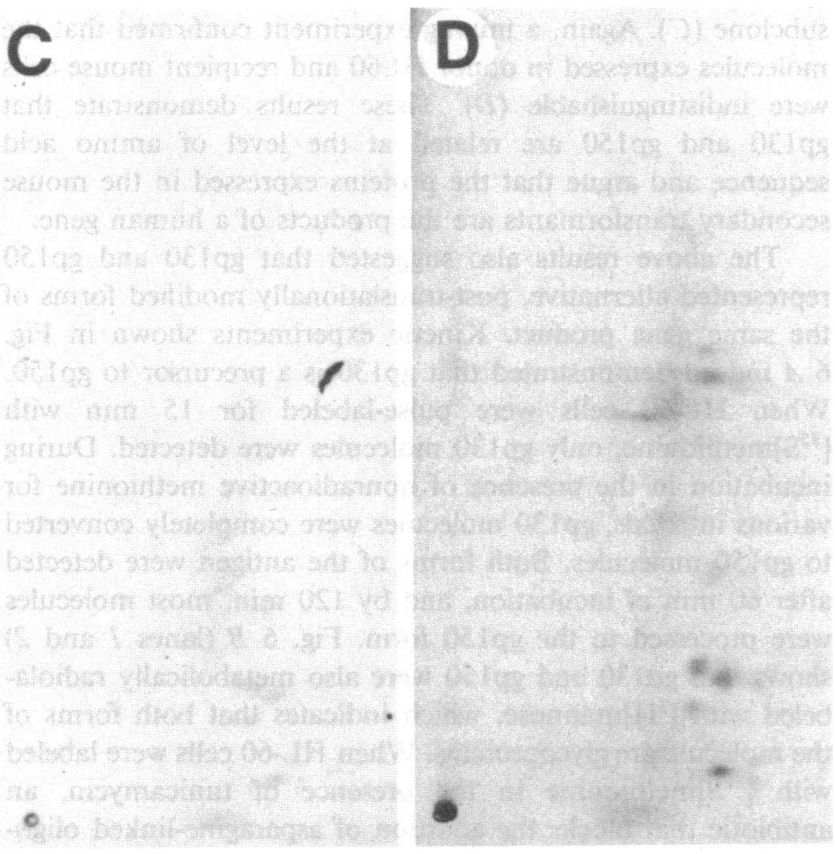

followed by ascending thin-layer chromatography (bottom to top). $\left[{ }^{35} S\right]$ Methionine-containing peptides were visualized by fluorography. $(A) \mathrm{gp} 150$ from HL-60 cells; $(B) \mathrm{gp} 130$ from HL-60 cells; $(C) \mathrm{gpl} 30$ from a secondary NIH/3T3 transformant; $(D)$ a mixture of equal quantities of radioactive $\mathrm{gp} 130$ molecules from HL-60 cells and the secondary NIH/3T3 transformant. 

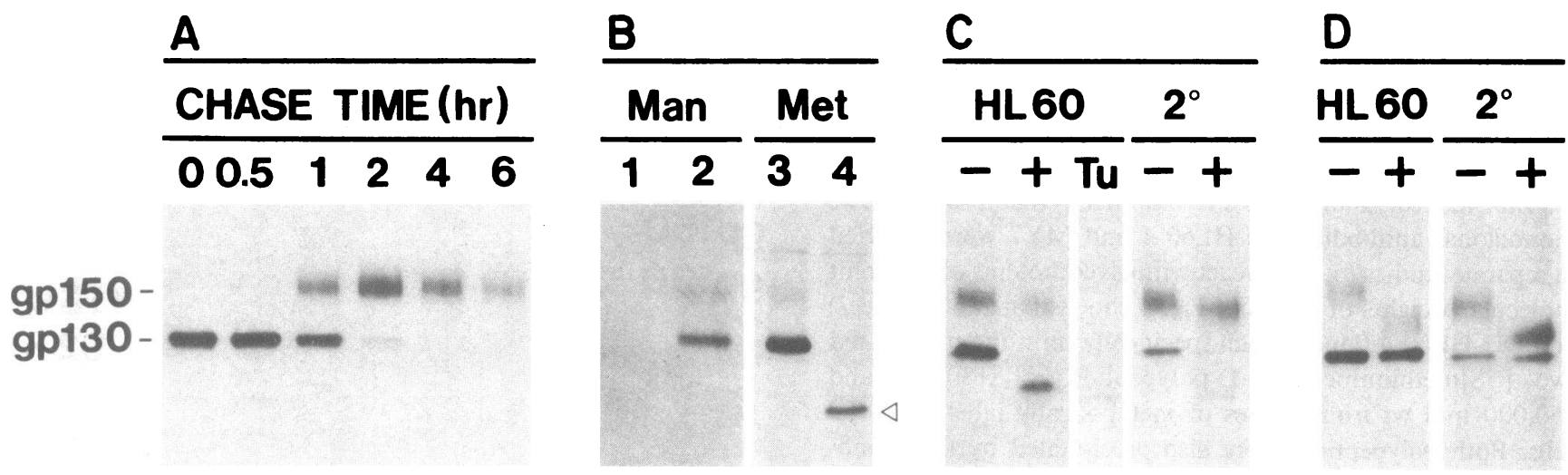

Figure 6. Biochemical analyses of $\mathrm{gpl} 130$ and $\mathrm{gp} 150$ molecules. $(A)$ Kinetics of formation of gp130 and gp150. Parallel cultures of HL-60 cells were labeled with $\left[{ }^{35} \mathrm{~S}\right]$ methionine for $15 \mathrm{~min}$ and then incubated in medium containing unlabeled methionine for the chase times indicated. Detergent lysates were precipitated with the monoclonal antibody DU-HL60-4 and immunoprecipitates were analyzed by electrophoresis in $7.5 \%$ polyacrylamide slab gels containing SDS. The positions of $\mathrm{gp} 130$ and $\mathrm{gp} 150$ are shown at the left of the figure. $(B)$ Glycosylation of $\mathrm{gpl} 30$ and $\mathrm{gp} 150$. Metabolically labeled lysates of HL-60 cells grown in the presence of $\left[{ }^{3} \mathrm{H}\right]$ mannose (lanes $l$ and 2) or $\left[{ }^{35} \mathrm{~S}\right]$ methionine (lanes 3 and 4 ) were precipitated with control myeloma protein (lane 1 ) or with DU-HL60-4 (lanes 2-4). Results with cells labeled in the presence of tunicamycin are shown in lane 4.
The arrow indicates the position of unglycosylated p1 10. (C) Sensitivity of glycoproteins to endo $H$. Immunoprecipitates from $\left[{ }^{35} S\right]$ methionine-labeled cells were incubated in the presence $(+)$ or absence (-) of enzyme before electrophoresis. Results with donor human cells (HL-60) and a recipient NIH/3T3 secondary transformant $\left(2^{\circ}\right)$ are compared. The lane marked Tu shows the position of the unglycosylated polypeptide (p110). (D) Sensitivity of glycoproteins to neuraminidase. Immunoprecipitates from [ $\left.{ }^{35} \mathrm{~S}\right]$ methioninelabeled cells were incubated in the presence $(+)$ or absence $(-)$ of neuraminidase before electrophoresis. Results with donor human cells (HL-60) and a recipient $\mathrm{NIH} / 3 \mathrm{~T} 3$ secondary transformant $\left(2^{\circ}\right)$ are compared. $C$ and $D$ represent composites of lanes run on the same gel.
HL-60 cells rendered indistinguishable tryptic fingerprints. The identity of the individual peptides was confirmed by experiments in which the two labeled products were mixed before analysis (data not shown). An identical tryptic fingerprint was also generated with gp130 expressed by a transformed NIH/3T3 subclone $(C)$. Again, a mixing experiment confirmed that the molecules expressed in donor HL60 and recipient mouse cells were indistinguishable $(D)$. These results demonstrate that gp130 and gp150 are related at the level of amino acid sequence and argue that the proteins expressed in the mouse secondary transformants are the products of a human gene.

The above results also suggested that gp130 and gp150 represented alternative, post-translationally modified forms of the same gene product. Kinetic experiments shown in Fig. $6 \mathrm{~A}$ indeed demonstrated that $\mathrm{gp} 130$ is a precursor to $\mathrm{gp} 150$. When HL-60 cells were pulse-labeled for $15 \mathrm{~min}$ with $\left[{ }^{35}\right.$ S $]$ methionine, only gp130 molecules were detected. During incubation in the presence of nonradioactive methionine for various intervals, gp130 molecules were completely converted to gp 150 molecules. Both forms of the antigen were detected after $60 \mathrm{~min}$ of incubation, and by $120 \mathrm{~min}$, most molecules were processed to the gp150 form. Fig. $6 B$ (lanes 1 and 2) shows that gp130 and gp150 were also metabolically radiolabeled with $\left[{ }^{3} \mathrm{H}\right]$ mannose, which indicates that both forms of the molecule are glycoproteins. When HL-60 cells were labeled with $\left[{ }^{35} \mathrm{~S}\right]$ methionine in the presence of tunicamycin, an antibiotic that blocks the addition of asparagine-linked oligosaccharide chains (33), a single unglycosylated polypeptide of 110,000 mol wt (p110) was immunoprecipitated (lane 4). A trace amount of this unglycosylated form was also detected early in the pulse-chase experiment shown in Fig. $6 \mathrm{~A}$.

The above results reflect those expected for glycoproteins that contain asparagine-linked oligosaccharide chains and are transported to the cell surface. In general, synthesis of these polypeptides on membrane-bound polyribosomes is coordinated with transport of nascent chains into the endoplasmic reticulum and with cotranslational addition of carbohydrate. Molecules in the cisternae of the endoplasmic reticulum contain endo $\mathrm{H}$ sensitive, $\mathrm{N}$-linked oligosaccharides that are rich in mannose. During transport through the Golgi complex, much of the mannose is removed, and the oligosaccharides are remodeled to form complex carbohydrate chains; these complex chains are resistant to endo $\mathrm{H}$ but are sensitive to neuraminidase if they contain terminal sialic acid residues (reviewed in reference 38). Fig. $6 C$ shows that gp130 molecules from both HL-60 and mouse transformants were sensitive to endo $H$ treatment, giving rise to molecules of lower apparent molecular weight. The endo H-treated gp130 molecules (lanes marked +) had only slightly slower electrophoretic mobility than did the unglycosylated polypeptide formed in the presence of tunicamycin (lane Tu), which shows that virtually all of the carbohydrate chains of gp130 were sensitive to endo $\mathrm{H}$ cleavage. Unlike gp130 molecules, gp150 molecules were relatively resistant to endo $\mathrm{H}$, which suggests that they contained complex carbohydrate chains. As shown in Fig. $6 \mathrm{D}$, gp150 molecules from both HL-60 cells and mouse transformants were sensitive to neuraminidase treatment, whereas $\mathrm{gp} 130$ molecules were completely resistant. The small difference in the electrophoretic mobilities of the gp150 molecules from human donor and mouse recipient cells (also seen in Fig. 4, lanes 3 and 5) probably reflects differences in the composition of the complex oligosaccharide chains synthesized in the two cell types.

These data suggested that gp150 molecules, processed in the Golgi complex, represent the cell surface form of the glycoprotein. To define the nature of the molecules on the plasma membrane, viable HL-60 cells were radioiodinated with lactoperoxidase, and detergent lysates were immunoprecipitated by use of the monoclonal antibody DU-HL60-4. Fig. 
7 (lane 3) shows that gp 150 molecules were the only radiolabeled species specifically precipitated from plasma membranes. The same results were obtained with a secondary NIH/3T3 transformant (lane 5). We conclude that the transferred human gene encodes a single polypeptide that is glycosylated and expressed at the surface of recipient mouse cells in a manner analogous to that observed in HL-60 cells.

\section{Discussion}

DNA-mediated gene transfer provides a new approach for studying cell surface molecules expressed as part of the human myeloid differentiation program. After transfection of DNA from a human myeloid cell line into mouse fibroblasts, rare transformants expressing myeloid cell surface antigens could be detected with each of four monoclonal antibodies and were selected with the fluorescence-activated cell sorter. Even though the frequency of transformed cells that expressed the antigens of interest was initially quite low, serial sorting of positive cells was used to enrich progressively for a population of primary mouse cell transformants that uniformly expressed the product of the mobilized gene. Repetition of the same procedures

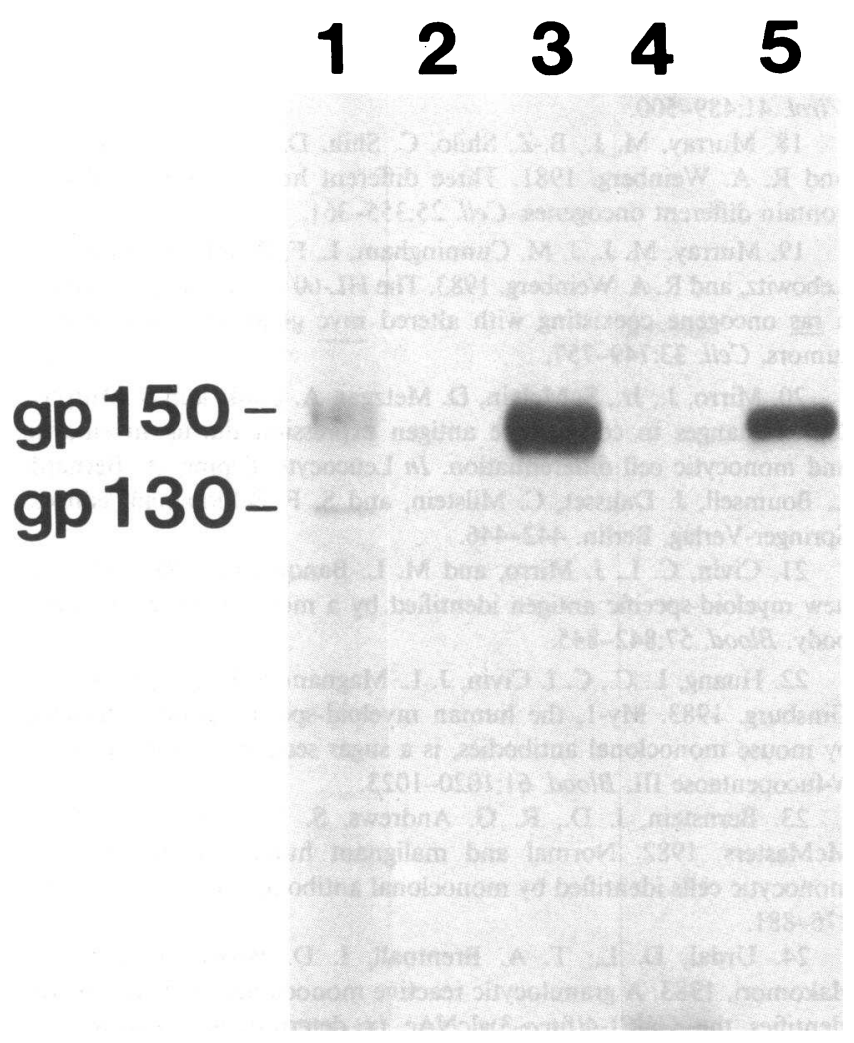

Figure 7. Expression of gp 150 on the plasma membrane of HL-60 cells and secondary NIH/3T3 transformants. Viable cells were enzymatically radioiodinated, and detergent lysates were immunoprecipitated with the antibodies indicated. Labeled proteins in immune complexes were denatured and analyzed in polyacrylamide gels containing SDS. The positions of $\left[{ }^{35} \mathrm{~S}\right]$ methionine labeled proteins precipitated from lysates of metabolically labeled cells are indicated in lane 1. Lysates of radioiodinated HL-60 cells (lanes 2 and 3) and transformed NIH/3T3 cells (lanes 4 and 5) were precipitated by use of nonimmune myeloma protein (lanes 2 and 4) or DU-HL60-4 monoclonal antibody (lanes 3 and 5). yielded secondary mouse cell transformants that contained a limited subset of human DNA sequences shared by independently derived subclones. The secondary subclones synthesized two specifically precipitable glycoprotein molecules (gp130 and gp150), which were also detected with the same monoclonal antibodies in parental HL-60 donor cells. Kinetic and biochemical experiments showed that gp130 was a precursor of gp150, differing from the cell surface form of the glycoprotein in the composition of its $\mathrm{N}$-linked oligosaccharide chains. A comparison of the $\left[{ }^{35} \mathrm{~S}\right]$ methionine-labeled tryptic cleavage products of gp130 and $\mathrm{gp} 150$ molecules from human and mouse cells showed unequivocally that these polypeptides are the product of the same gene. We conclude that the mobilized human DNA sequences in secondary transformants encode gp1 30 and gp150 and provide the first direct evidence that the monoclonal antibodies DU-HL60-4, MY7, MCS.2, and SJ-D1 react with epitopes on a single glycoprotein. These results are consistent with previous observations that these four monoclonal antibodies react with similar subsets of normal and malignant human myeloid cells $(3-7,20)$.

The pattern of expression of $\mathrm{gp} 150$ by cells in the human myeloid lineage is based primarily on studies with the monoclonal antibodies DU-HL60-4 $(5,7)$ and MY7 $(3,6,39)$. gp150 has a panmyeloid distribution, since it can be identified on normal marrow granulocytic and monocytic cells at all recognizable levels of differentiation. The molecule is unusual in its expression, in that it is detectable only on a fraction of cells at each stage of differentiation, in contrast to most differentiation-specific antigens, which tend to be uniformly expressed by cells of a given morphologic type (39). gp150 is also expressed by a subset of human CFU-C, with preferential expression in regenerating marrow and in cells in the DNA synthesis phase of the cell cycle. Based on increased expression of the molecule by progenitors engaged in cell division, Griffin et al. (39) proposed that gp 150 could be analogous to certain cell surface glycoproteins of lymphocytes that are present at low levels on resting cells but are induced by mitogenic stimulation. The elaboration of gp150 by human myeloid leukemia cells but not by lymphoid tumors has led to the use of monoclonal antibodies to gp150 as diagnostic tools. Whether the expression of gp150 has any relation to the process of malignant transformation in myeloid leukemia remains unclear. The selective expression of $\mathrm{gp} 150$ by proliferative human granulocyte-monocyte progenitors and by their leukemic derivatives raises the possibility that the glycoprotein might function to influence the proliferative capacity of myeloid cells.

Studies with the monoclonal antibody DU-HL60-4 also demonstrated antigen in sections of renal tissue in proximal tubules and Bowman's capsules and in testicular cells (5). It is not yet known whether the antibody reacts with gp 150 or with another molecule that shares an epitope recognized by DUHL60-4. The presence of gp150 on nonhematopoietic tissues suggests that the glycoprotein could play some general physiologic role. This finding may be analogous to results obtained with the antibody OKT-9, which was originally found to bind to immature $T$ cells (40) but later shown to recognize the more prevalent human transferrin receptor (41).

Conventional approaches to cloning genes detectable with monoclonal reagents usually involve immunoselection of polyribosomes and synthesis of complementary DNA from a 
limited subset of recovered messenger RNA templates. The ability to isolate the gene encoding gp150 in a mouse cell genetic background provides an alternative approach to obtaining DNA clones (9). In principle, the construction of a genomic DNA library by use of secondary transformants, and probing of the library for human repetitive DNA sequences should allow portions of the gene to be readily cloned. Since the cloned genes would similarly be expected to be expressed in mouse cell recipients, DNA-mediated gene transfer can be used to verify the functional integrity of the cloned sequences. The approach should be generally applicable to genes encoding cell surface antigens expressed on normal or malignant cells, including antigens expressed in fresh tissues from patients.

\section{Acknowledgments}

We thank Edward Wingfield, Elizabeth Mann, and Beth Ward for excellent technical assistance, John Gilbert for editorial review, Richard S. Metzgar of Duke University (Durham, NC) for gifts of monoclonal antibodies DU-HL60-1, DU-HL60-3, DU-HL60-4, Joseph Mirro of St. Jude Children's Research Hospital (Memphis, TN) for SJ-D1, Jun Minnowada of Loyola University (Chicago, IL) for MCS.2, Curt I. Civin of Johns Hopkins University (Baltimore, MD) for MY1, Linda S. Martin of the Centers for Disease Control (Atlanta, GA) for G2, Peter C. L. Beverly of the Imperial Cancer Research Fund (London, England) for TG1, Peter Rieber of University of Munich for G1120, and Irwin D. Bernstein of Fred Hutchinson Cancer Research Center (Seattle, WA) for L4F3 and 1G10.

This work was supported by Cancer Center grant CA21765, Leukemia Program Project grant CA20180, and by the American Lebanese Syrian Associated Charities (ALSAC). Dr. Rettenmier is supported by Biomedical Research Support grant RR-05584-19 from the National Institutes of Health to St. Jude Children's Research Hospital.

\section{References}

1. Till, J. E., and E. A. McCulloch. 1961. A direct measurement of the radiation sensitivity of normal mouse bone marrow cells. Radiat. Res. 14:213-222.

2. Pike, B. L., and W. A. Robinson. 1970. Human bone marrow colony growth in agar-gel. J. Cell Physiol. 76:77-84.

3. Griffin, J. D., J. Ritz, L. M. Nadler, and S. F. Schlossman. 1981. Expression of myeloid differentiation antigens on normal and malignant myeloid cells. J. Clin. Invest. 68:932-941.

4. Bernard, A., L. Boumsell, and C. Hill. 1984. Joint report of the first international workshop on human leucocyte differentiation antigens by the investigators of the participating laboratories. In Leucocyte Typing. A. Bernard, L. Boumsell, J. Dausset, C. Milstein, and S. F. Schlossman, editors. Springer-Verlag, Berlin. 82-108.

5. McKolanis, J. R., O. J. Finn, and R. S. Metzgar. 1983. Characterization of human myelomonocytic antigens using monoclonal antibodies. In Non-HLA Antigens in Health, Aging and Malignancy. Alan R. Liss, New York. 145-156.

6. Griffin, J. D., and S. F. Schlossman. Expression of myeloid differentiation antigens in acute myeloblastic leukemia. In Leucocyte Typing. A. Bernard, L. Boumsell, J. Dausset, C. Milstein, S. F. Schlossman, editors. Springer-Verlag, Berlin. 404-410.

7. McKolanis, J. R., M. J. Borowitz, F. L. Tuck, and R. S. Metzgar. 1984. Membrane antigens of human myeloid cells defined by monoclonal antibodies. In Leucocyte Typing. A. Bernard, L. Boumsell, J. Dausset, C. Milstein, and S. F. Schlossman, editors. Springer-Verlag, Berlin. 387-394.

8. Kavathas, P., and L. A. Herzenberg. 1983. Stable transformation of mouse $\mathrm{L}$ cells for human membrane $\mathrm{T}$-cell differentiation antigens,
HLA and $\beta_{2}$-microglobulin: selection by fluorescence-activated cell sorting. Proc. Natl. Acad. Sci. USA. 80:524-528.

9. Kühn, L. C., A. McClelland, and F. H. Ruddle. 1984. Gene transfer, expression, and molecular cloning of the human transferrin receptor gene. Cell. 37:95-103.

10. Jainchill, J. S., S. A. Aaronson, and G. J. Todaro. 1969. Murine sarcoma and leukemia viruses: assay using clonal lines of contact inhibited mouse cells. J. Virol. 4:549-553.

11. Kit, S., D. Dubbs, L. Piekarski, and T. Hsu. 1963. Detection of thymidine kinase activity from $\mathrm{L}$ cells resistant to bromodeoxyuridine. Exp. Cell Res. 31:297-312.

12. Collins, S. J., F. W. Ruscetti, R. E. Gallagher, and R. C. Gallo. 1978. Terminal differentiation of human promyelocytic leukemia cells induced by dimethyl sulfoxide and other polar compounds. Proc. Natl. Acad. Sci. USA. 75:2458-2462.

13. Graham, F. L., and A. J. Van der Eb. 1973. Transformation of rat cells by DNA of human adenovirus 5. Virology. 54:536-539.

14. Lowy, D. R., E. Rands, and E. M. Scolnick. 1978. Helperindependent transformation by unintegrated Harvey sarcoma virus DNA. J. Virol. 26:291-298.

15. Wigler, M., A. Pellicer, S. Silverstein, and R. Axel. 1978. Biochemical transfer of single-copy eucaryotic genes using total cellular DNA as donor. Cell. 14:725-731.

16. Perucho, M., M. Goldfarb, K. Shimizu, C. Lama, J. Fogh, and M. Wigler. 1981. Human tumor-derived cell lines contain common and different transforming genes. Cell. 27:467-476.

17. Donner, L., L. A. Fedele, C. F. Garon, S. J. Anderson, and C. J. Sherr. 1982. McDonough feline sarcoma virus: characterization of the molecularly cloned provirus and its feline oncogene (v-fms). $J$. Virol. 41:489-500.

18. Murray, M. J., B.-Z. Shilo, C. Shih, D. Cowing, H. W. Hsu, and R. A. Weinberg. 1981. Three different human tumor cell lines contain different oncogenes. Cell. 25:355-361.

19. Murray, M. J., J. M. Cunningham, L. F. Parada, F. Dautry, P. Lebowitz, and R. A. Weinberg. 1983. The HL-60 transforming sequence: a ras oncogene coexisting with altered myc genes in hematopoietic tumors. Cell. 33:749-757.

20. Mirro, J., Jr., S. Melvin, D. Metzgar, A. Look, and S. Murphy. 1984. Changes in cell surface antigen expression during myelocytic and monocytic cell differentiation. In Leucocyte Typing. A. Bernard, L. Boumsell, J. Dausset, C. Milstein, and S. F. Schlossman, editors. Springer-Verlag, Berlin. 442-446.

21. Civin, C. I., J. Mirro, and M. L. Banquerigo. 1981. My-1, a new myeloid-specific antigen identified by a mouse monoclonal antibody. Blood. 57:842-845.

22. Huang, L. C., C. I. Civin, J. L. Magnani, J. H. Shaper, and V. Ginsburg. 1983. My-1, the human myeloid-specific antigen detected by mouse monoclonal antibodies, is a sugar sequence found in lacto$N$-fucopentaose III. Blood. 61:1020-1023.

23. Bernstein, I. D., R. G. Andrews, S. F. Cohen, and B. E. McMasters. 1982. Normal and malignant human myelocytic and monocytic cells identified by monoclonal antibodies. J. Immunol. 128: 876-881.

24. Urdal, D. L., T. A. Brentnall, I. D. Bernstein, and S.-I. Hakomori. 1983. A granulocytic reactive monoclonal antibody, 1G10, identifies the Gal $\beta 1-4$ (fuc $\alpha$-3)glcNAc (x determinant) expressed in HL60 cells on both glycolipid and glycoprotein molecules. Blood. 62: 1022-1026.

25. Andrews, R. G., B. Torok-Storb, and I. D. Bernstein. 1983. Myeloid-associated differentiation antigens on stem cells and their progeny identified by monoclonal antibodies. Blood. 62:124-132.

26. Andrews, R. G., T. A. Brentnall, B. Torok-Storb, and I. D. Bernstein. 1984. Stages of myeloid differentiation identified by monoclonal antibodies. In Leucocyte Typing. A. Bernard, L. Boumsell, J. Dausset, C. Milstein, and S. F. Schlossman, editors. Springer-Verlag, Berlin. 398-404. 
27. Hanjan, S. N. S., J. F. Kearney, and M. D. Cooper. 1982. A monoclonal antibody (MMA) that identifies a differentiation antigen on human myelomonocytic cells. Clin. Immunol. Immunopathol. 23:172-188.

28. Nadler, L. M., P. Stashenko, R. Hardy, J. M. Pesando, E. J. Yunis, and S. F. Schlossman. 1981. Monoclonal antibodies defining serologically distinct HLA-D/DR related Ia-like antigens in man. Hum. Immunol. 1:77-90.

29. Southern, E. M. 1975. Detection of specific sequences among DNA fragments separated by gel electrophoresis. J. Mol. Biol. 98:503517.

30. Britten, R. J., and D. E. Kohne. 1968. Repeated sequences in DNA. Science (Wash. DC). 161:529-540.

31. Rigby, P. W. J., M. Dieckmann, C. Rhodes, and P. Berg. 1977. Labeling deoxyribonucleic acid to high specific activity in vitro by nick translation with DNA polymerase I. J. Mol. Biol. 113:237-251.

32. Sherr, C. J., L. A. Fedele, L. Donner, and L. P. Turek. 1979. Restriction endonuclease mapping of unintegrated proviral DNA of Snyder-Theilen feline sarcoma virus: localization of sarcoma-specific sequences. J. Virol. 32:860-875.

33. Kuo, S. C., and J. O. Lampen. 1974. Tunicamycin-an inhibitor of yeast glycoprotein synthesis. Biochem. Biophys. Res. Commun. 58:287-295.

34. Laemmli, U. K. 1970. Cleavage of structural proteins during the assembly of the head of bacteriophage T4. Nature (Lond.). 227:680685 .

35. Rettenmier, C. W., R. E. Karess, S. M. Anderson, and H. Hanafusa. 1979. Tryptic peptide analysis of avian oncovirus gag and pol gene products. J. Virol. 32:102-113.

36. Newman, R., D. Domingo, J. Trotter, and I. Trowbridge. 1983. Selection and properties of a mouse L-cell transformant expressing human transferrin receptor. Nature (Lond.). 304:643-645.

37. Todaro, G. J. 1972. "Spontaneous" release of type C viruses from clonal lines of "spontaneously" transformed Balb/3T3 cells. Nature New Biol. (Lond.). 240:157-160.

38. Kornfeld, S. 1982. Oligosaccharide processing during glycoprotein biosynthesis. In The Glycoconjugates. Vol. 3. M. Horowitz and W. Pigman, editors. Academic Press, New York. 3-23.

39. Griffin, J. D., J. Ritz, R. P. Beveridge, J. M. Lipton, J. F. Daley, and S. F. Schlossman. 1983. Expression of MY7 antigen on myeloid precursor cells. Int. J. Cell Cloning. 1:33-48.

40. Reinherz, E. L., P. C. Kung, G. Goldstein, R. H. Levey, and S. F. Schlossman. 1980. Discrete stages of human intrathymic differentiation: analysis of normal thymocytes and leukemic lymphoblasts of T cell lineage. Proc. Natl. Acad. Sci. USA. 77:1588-1592.

41. Goding, J. W., and G. F. Burns. 1981. Monoclonal antibody OKT-9 recognizes the receptor for transferrin on human acute lymphocytic leukemia cells. J. Immunol. 127:1256-1258. 